\title{
NUEVA APORTACIÓN A LA OBRA ESCULTÓRICA DE BLAS MOLNER. LA VIRGEN DE LA SOLEDAD DE MORÓN DE LA FRONTERA
}

\author{
POR JuAn Miguel GonZález GómEz
}

\begin{abstract}
Blas Molner, escultor e imaginero valenciano (1737-1812), es el máximo exponente del Neoclasicismo escultórico sevillano. Como Director del Area de Escultura y Director General de la Real Escuela de las Tres Nobles Artes de Sevilla, legó a la capital de Andalucía lo más representativo de su quehacer plástico. En este trabajo catalogamos una imagen suya, totalmente inédita hasta el momento. Se trata de una Dolorosa de Morón de la Frontera. De esta forma, pues, enriquecemos la nómina de sus obras documentadas.
\end{abstract}

Blas Molner, the Valencian sculptor and image-maker (1737-1812), is the prime exponent of sculptural neoclassicism in Seville. As Director of Sculpture and Director General of the Royal School of the Three Noble Arts in Seville, he left to the Andalusian capital the most representative of his artistic creations. In this article we catalogue one of his images, hitherto unknown: a Grieving Virgin from Morón de la Frontera, thus adding to the list of his documented works.

En el tomo II del homenaje ofrecido, en 1992, por la revista Laboratorio de Arte, de la Universidad de Sevilla, al profesor Jorge Bernales Ballesteros, colaboraron la Dra. García Gainza y el Dr. Roda Peña con dos interesantes contribuciones sobre la vida y obra del escultor e imaginero Blas Molner ${ }^{1}$. A todo ello

1. GARCÍA GAINZA, María Concepción: "Un grupo de la Asunción firmado por Blas Molner", en Laboratorio de Arte, n. ${ }^{2}$ 5, tomo П, Sevilla, 1992, pp. 403-406. RODA PEÑA, Jose: "A propósito de una escultura dieciochesca de San José", en Laboratorio de Arte, n. ${ }^{9} 5$, tomo II, Sevilla, 1992, pp. 369-378. 
sumamos, ahora, el presente trabajo, gracias al que añadimos una pieza más a la escueta nómina de obras documentadas de dicho artista valenciano, que dejó en Sevilla y su provincia lo mejor y más significativo de su quehacer artístico.

Se trata, en esta ocasión, de una Dolorosa, la única perfectamente documentada que poseemos, hasta el momento, de Blas Molner, genuino representante del Neoclasicismo escultórico sevillano. De ahí la trascendental importancia de esta imagen mariana, que pasa a ser obligado punto de referencia, dentro de dicho modelo iconográfico, para el examen de las seculares atribuciones mantenidas hasta ahora.

Sabido es que Blas Molner nació en Valencia en 1737. Sus padres fueron Jaime Molner y Felipa Zamora. El 27 de agosto de 1755, ambos suscriben un contrato de aprendizaje para su hijo con el maestro Tomás Llorens. Dicho contrato obligaba a este último, durante cuatro años, a enseñarle a su joven discípulo el oficio y la doctrina cristiana. Y el padre, a lo largo de ese período cronológico, afrontaría la manutención, vestido y calzado del mismo ${ }^{2}$. No obstante, posteriormente, debió complementar nuestro artista su formación en la Academia de San Carlos ${ }^{3}$.

Blas Molner llegaría a Sevilla en la década de los setenta, ya que aparece muy vinculado a la fundación, en 1775, de la Escuela de las Tres Nobles Artes de la capital de Andalucía. En aquel centro ostentó sucesivamente los cargos de Director del Area de Escultura y Director General desde 1793 a 1812, año de su fallecimiento. A este último cargo accedió tras la muerte D. Francisco Miguel

2. GARCÍA GAINZA, María Concepción: "Un grupo de la Asunción firmado por Blas Molner". Op. cit., p. 404.

3. VIÑAZA, Conde de la: Adiciones al Diccionario Histórico de los más ilustres profesores de las Bellas Artes en España de Juan Agustín Ceán Bermúdez, tomo III, Madrid, 1894, p. 79. SERRANO Y ORTEGA, Manuel: Noticia histórico-artística de la sagrada imagen de Jesús Nazareno que con el titulo del Gran Poder se venera en su Capilla del templo de San Lorenzo de esta ciudad, Sevilla, 1898, p. 108. GESTOSO Y PÉREZ, José: Ensayo de un diccionario de los artífices que florecieron en Sevilla desde el siglo XIII al XVIII inclusive, tomo I, Sevilla, 1899, p. 227. BANDA Y VARGAS, Antonio de la: "La imaginería procesional sevillana en los siglos XIX y XX", en Boletín de las Cofradías de Sevilla, Año XXI, n.․242, noviembre 1979, p. 18. GONZÁLEZ GÓMEZ, Juan Miguel: "Imágenes de las cofradías sevillanas desde el Academicismo al Expresionismo realista", en Las cofradias de Sevilla en el siglo de las crisis, Sevilla, 1991, p. 113. BANDA Y VARGAS, Antonio de la: De la llustración a nuestros días, en "Historia del Arte en Andalucía", tomo VIII, Sevilla, 1991, p. 54. GONZÁLEZ GÓMEZ, Juan Miguel y RODA PEÑA, José: Imaginería procesional de la Semana Santa de Sevilla, Sevilla, 1991, p. 143. RODA PEÑA, José: "A propósito de una escultura dieciochesca de San José". Op. cit., p. 373. 
Jiménez ${ }^{4}$. Y, además, fue profesor de Delineación y lavado de planos en el Colegio de San Telmo, entre el 19 de marzo y el 31 de octubre de $1787^{5}$.

Alejandro Guichot, en 1925, al referirse a este escultor valenciano, comenta que Blas Molner inició en Sevilla, a partir del referido año de 1775, "una nueva era en la enseñanza, desviándola de los extravíos y dirigiéndola hacia el buen gusto" ${ }^{6}$. En efecto, durante su estancia en nuestra ciudad, época de su madurez artística, profundizó en el estilo academicista iniciado por su compañero Cristóbal Ramos, Teniente de Escultura en la mencionada Real Escuela de las Tres Nobles Artes de Sevilla. Con sus finas maneras alcanza, pues, el maridaje perfecto entre el sentido tradicional de nuestra plástica barroca y la corrección propia del gusto neoclásico ${ }^{?}$.

A continuación ofrecemos una cumplida relación, totalmente actualizada, de su quehacer artístico. Entre sus obras documentadas reseñamos: el retablo de Nuestra Señora de Belén, en la parroquial sevillana de San Lorenzo, de $1780^{\circ}$; el grupo escultórico de la Asunción de Echalar (Navarra), de 1780 ó $1781^{\text {9; }}$ el San José de la Hermandad de Pasión, en la iglesia parroquial del Divino Salvador de Sevilla, de $1781^{10}$; las estanterías del Archivo General de Indias, antigua Casa Lonja, de $1788^{11}$; el San Elías de la iglesia de la Concepción (Los Descalzos) de Ecija, de $1791^{12}$; el templete del presbiterio de la parroquia hispalense de Santa Cruz, de 1792 13; el San Gil de la parroquial ecijana de dicha advocación, de

4. OSSORIO Y BERNARD, M.: Galería biográfica de artistas españoles del siglo XIX, Madrid, 1975, pp. 454-455. GONZÁLEZ GÓMEZ, Juan Miguel: “Imágenes de las cofradías sevillanas desde el Academicismo al Expresionismo realista". Op. cit., pp. 113 y 125. GONZÁLEZ GÓMEZ, Juan Miguel y RODA PEÑA, José: Imaginería procesional de la Semana Santa de Sevilla, Op. cit., p. 143. RODA PEÑA, José: “A propósito de una escultura dieciochesca de San José”. Op. cit., pp. 373-374.

5. FALCÓN MÁRQUEZ, Teodoro: El palacio de San Telmo, Sevilla, 1991, p. 173.

6. GUICHOT Y SIERRA, Alejandro: El Cicerone de Sevilla. Monumentos y Artes Bellas, tomo I, Sevilla, 1925, p. 412.

7. GONZÁLEZ GÓMEZ, Juan Miguel: "Imágenes de las cofradías sevillanas desde el Academicismo al Expresionismo realista". Op. cit., p. 113.

8. SERRERA CONTRERAS, Juan Miguel: Pedro Villegas Marmolejo, Sevilla, 1976, p. 79. MORALES, Alfredo J.: La iglesia de San Lorenzo de Sevilla, Sevilla, 1981, p. 53.

9. GARCÍA GAINZA, María Concepción: "Un grupo de la Asunción firmado por Blas Molner". Op. cit., pp. 403-406. 369-378.

10. RODA PEÑA, José: “A propósito de una escultura dieciochesca de San José”. Op. cit., pp.

11. GESTOSO Y PÉREZ, José: Sevilla Monumental y Artística, tomo III, Sevilla, 1892, p. 237.

12. MORALES, A.; SANZ, M." J.; SERRERA, J.M. y VALDIVIESO, E.: Guía artística de Sevilla y su provincia, Sevilla, 1981, pp. 419-420.

13. GONZÁLEZ DE LEÓN, Félix: Noticia artística de Sevilla, Sevilla, 1844, p. 424. GESTOSO Y PÉREZ, José: Sevilla Monumental y Artística, tomo III, Op. cit., pp. 317-318. VIÑAZA, Conde de la: Adiciones al Diccionario Histórico de los más ilustres profesores de las Bellas Artes en España de Juan Agustín Ceán Bermúdez, tomo III, op. cit., p. 79. BANDA Y VARGAS, Antonio de la: De la llustración a nuestros días. Op. cit., p. 52. 
$1799^{\text {14; }}$ La Piedad de Lucena de Córdoba, de 1799 15. y la Dolorosa de Morón de la Frontera que catalogamos en el presente trabajo.

Además, en Sevilla, se le atribuye con fiabilidad: el grupo de la Trinidad de la iglesia de Santa María la Blanca ${ }^{16}$, el San José de la parroquia de Santa Cruz ${ }^{17}$, el San Rafael y el Ángel de la Guarda del convento del Santo Ángel ${ }^{18}$, la Asunción del Hospital de la Paz ${ }^{19}$, el San Hermenegildo y el San Luis del retablo de San Fernando en la parroquia del Divino Salvador ${ }^{20}$, la Virgen de los Dolores de la Hermandad de las Penas del templo parroquial de San Vicente ${ }^{21}$, y la Magdalena de la Cofradía de la Sagrada Lanzada en la iglesia de San Martín ${ }^{22}$. En Huelva, le asignamos la Dolorosa del Rosario en la parroquial de

14. HERNÁNDEZ DÍAZ, José; SANCHO CORBACHO, Antonio y COLLANTES DE TERÁN, Francisco: Catálogo Arqueológico y Artístico de la provincia de Sevilla, tomo III, Sevilla, 1951, p. 145. MORALES, A.; SANZ, M." J.; SERRERA, J.M. y VALDIVIESO, E.: Guía artística de Sevilla y su provincia. Op. cit., p. 410.

15. HERNÁNDEZ DÍAZ, José: "Aportaciones recientes sobre imaginería e imagineros en el Barroco sevillano", en Boletín de Bellas Artes, 2. Epoca, n. XVII. Sevilla, 1989, p. 107.

16. GONZÁLEZ DE LEÓN, Félix: Noticia artística de Sevilla. Op. cit., p. 105. GUERRERO LOVILLO, José: Guía artística de Sevilla y su provincia. Op. cit., p. 121. MORALES, A.; SANZ, M. ${ }^{\mathrm{a}}$ J.; SERRERA, J.M. y VALDIVIESO, E.: Guía artistica de Sevilla y su provincia. Op. cit., p. 87. BANDA Y VARGAS, Antonio de la: De la ilustración a nuestros días. Op. cit., p. 56.

17. MORALES, A.; SANZ, M. J.; SERRERA, J.M. y VALDIVIESO, E.: Guía artística de Sevilla y su provincia. Op. cit., p. 80.

18. GONZÁLEZ DE LEÓN, Félix: Noticia artística de Sevilla. Op. cit., p. 167. GESTOSO Y PÉREZ, José: Sevilla Monumental y Artística, tomo III, op. cit., p. 300. VIÑAZA, Conde de la: Adiciones al Diccionario histórico de los más ilustres profesores de las Bellas Artes en España de Juan Agustín Ceán Bermúdez, tomo III. Op. cit., p. 79. BANDA Y VARGAS, Antonio de la: De la Ilustracion a nuestros días. Op. cit., p. 56.

19. GONZÁLEZ DE LEÓN, Félix: Noticia artística de Sevilla. Op. cit., p. 124. GESTOSO Y PÉREZ, José: Sevilla Monumental y Artística, tomo III, op. cit., p. 371. MORALES, A.; SANZ, M. ${ }^{2}$ J.; SERRERA, J.M. y VALDIVIESO, E.: Guia artística de Sevilla y su provincia. Op. cit., p. 72.

20. GUERRERO LOVILLO, José: Guía artística de Sevilla. Op. cit., p. 130. MORALES, A.; SANZ, M. J.; SERRERA, J.M. y VALDIVIESO, E.: Guía artística de Sevilla y su provincia. Op. cit., p. 70.

21. GUICHOT Y SIERRA, Alejandro: El Cicerone de Sevilla. Monumentos y Artes Bellas, tomo I, Op. cit., p. 412. BANDA Y VARGAS, Antonio de la: "La imaginería procesional sevillana en los siglos XIX y XX", en Boletín de las Cofradías de Sevilla, n.. 242, Sevilla, noviembre de 1979, p. 18. GONZÁLEZ GÓMEZ, Juan Miguel: "Imágenes de las cofradías sevillanas desde el Academicismo al Expresionismo realista”. Op. cit., pp. 125-126. BANDA Y VARGAS, Antonio de la: De la Ilustración a nuestros días. Op. cit., p. 56. GONZÁLEZ GÓMEZ, Juan Miguel y RODA PEÑA, José: Imaginería procesional de la Semana Santa de Sevilla. Op. cit., p. 143.

22. BERMEJO Y CARBALLO, José: Glorias Religiosas de Sevilla, Sevilla, 1882, p. 348. MONTESINOS MONTESINOS, Carmen: El escultor sevillano Cristóbal Ramos (1725-1799), Sevilla, 1986, p. 62. GONZÁLEZ GÓMEZ, Juan Miguel: "Imágenes de las cofradías sevillanas desde el Academicismo al Expresionismo realista". Op. cit., p’. 166-168. BANDA Y VARGAS, Antonio de la: De la llustración a nuestros días. Op. cit., p. 56. 
Bonares ${ }^{23}$. En Lucena de Córdoba le atribuyen un Crucifijo de marfil y un San Juan Nepomuceno en la parroquia de San Mateo ${ }^{24}$. Y en la baja Extremadura se sitúan dentro de su producción escultórica: un Cristo atado a la columna, en el convento de las clarisas de Zafra, de 1755; otro Cristo flagelado, en Montijo; y un Crucificado, en Zahínos ${ }^{25}$.

Es obvio que, con el transcurso del tiempo, algunas obras suyas hayan desaparecido o se desconozca su actual paradero. En este sentido, podemos recordar el misterio de la Piedad de la extinguida parroquia hispalense de San Miguel. Dicho grupo, trabajado en pasta policromada, estaba compuesto por la Virgen con el Cristo yacente sobre su regazo, el discípulo amado, genuflexo, a la cabecera; y María Magdalena, a los pies ${ }^{26}$. Asimismo debemos mencionar la Santa Lutgarda del retablo de la Virgen de la Antigua, en la iglesia sevillana de San Juan de la Palma ${ }^{27}$. Y una escultura de San Juan Bautista, adosada a un tablero lígneo, con la siguiente leyenda: "Copia de Pedro Delgado por Blas Molner, N.I. de va”". Esta copia, según Gestoso, formaba parte de los fondos del Museo de Bellas Artes de Sevilla ${ }^{28}$. No obstante, actualmente, no figura reseñada en los inventarios del mismo.

Por último, antes de concluir el variado elenco de las obras artísticas documentadas y atribuidas a Blas Molner, debemos anotar también su actividad como restaurador. Por entonces, un mismo escultor alternaba la labor escultórica personal, propia de su iniciativa creadora, con las tareas simplemente restauradoras. En este caso, sirve para ilustrar dicha faceta artística su intervención en la corona de espinas de Nuestro Padre Jesús del Gran Poder y en los ángeles pasionarios que enriquecen sus andas procesionales, en $1776^{29}$. Y hacia 1812, poco antes de

23. GONZÁLEZ GÓMEZ, Juan Miguel y CARRASCO TERRIZA, Manuel: Escultura Mariana Onubense, Huelva, 1981, p. 248. RODA PEÑA, José: "Antiguas imágenes titulares de las cofradías sevillanas", en Las cofradías de Sevilla en el siglo de las crisis, Sevilla, 1991, pp. 222-223. GONZÁLEZ GÓMEZ, Juan Miguel y RODA PEÑA, José: Imaginería procesional de la Semana Santa de Sevilla. Op. cit., p. 236.

24. AA.VV.: Catálogo artístico y monumental de la provincia de Córdoba, tomo V, Córdoba, 1987 , p. 108.

25. BANDA Y VARGAS, Antonio de la: "Huellas artísticas andaluzas en la Baja Extremadura", en Estudios de Arte Español, Sevilla, 1974, p. 25. Idem: De la llustración a nuestros días. Op. cit., pp. 56-57.

26. GONZÁLEZ DE LEÓN, Félix: Noticia artistica de Sevilla. Op. cit., p. 40.

27. Ibidem, p. 85.

28. GESTOSO Y PÉREZ, José: Diccionario de artífices que florecieron en Sevilla desde los siglos XIII al XVIII, inclusive. Tomo I. Sevilla, 1899, p. 227. GARCÍA GAINZA, María Concepción: "Un grupo de la Asunción firmado por Blas Molner". Op. cit., p. 405.

29. CARRERO RODRÍGUEZ, Juan: Anales de las cofradías sevillanas, Sevilla, 1991, p. 360. GONZÁLEZ GÓMEZ, Juan Miguel y RODA PEÑA, José: "Imagineros e imágenes de la Semana Santa sevillana (1563-1763)", en Las Cofradías de Sevilla en la modernidad, Sevilla, 1988, p. 184. Idem: Imaginería procesional de la Semana Santa de Sevilla. Op. cit., p. 93. 
morir, modificó sustancialmente la desaparecida Virgen del Valle, patrona de Manzanilla (Huelva), para adaptarla al gusto de la época ${ }^{30}$.

Acto seguido, tras esta breve síntesis sobre la biografía y producción plástica de Blas Molner, facilitamos la catalogación y estudio de la efigie mariana que nos ocupa.

\section{VIRGEN DE LA SOLEDAD}

Colección particular. Morón de la Frontera.

Imagen de candelero para vestir.

Mide $1,74 \mathrm{~m}$. de alto.

Obra de Blas Molner.

Fines del siglo XVIII. (Lám. 1).

Según apuntamos líneas atrás, esta Dolorosa es la única documentada que poseemos, hasta el momento, del referido imaginero valenciano. Afortunadamente, aún ostenta en la espalda una esclarecedora inscripción que dice: "LA YSO EN SEVILLA DN. BLAZ MOLNER, BALENSIANO, VIVE EN LA ALAMEDA" (Lám. 2). Gracias a ella se prueba fehacientemente la autoría de la obra, su lugar de ejecución, el origen y la residencia del artista en nuestra ciudad. Sin embargo, se silencia la fecha de ejecución de la misma.

Dicha escultura, procedente de la iglesia de Nuestra Señora de la Victoria de Morón de la Frontera (Sevilla), se conserva en una colección particular de esa población de la Sierra Sur, en la casa n. ${ }^{\circ} 2$ de la calle Cánovas del Castillo, tradicionalmente conocida por "La Carrera" 31.

Iconográficamente, la Soledad de María, desde las primeras representaciones del Speculum humanae salvationis, de época medieval, pasando por las desgarradoras expresiones del arte hispano-flamenco, hasta la elocuente imaginería polícroma del Barroco, ha ido configurándose primero como Virgen llorosa, rodeada de los gozos y sufrimientos de Cristo, luego acompañada por San Juan Evangelista, y finalmente, sola al pie de la cruz. Se suele representar con las manos

30. ALONSO MORGADO, José: "La prodigiosa imagen de María Santísima del Valle, venerada en su santuario cerca de la villa de Manzanilla". Sevilla Mariana, t. IV., Sevilla, 1883, pp. 330 331. Reseña Histórica de la Sagrada Imagen de Ntra. Sra. del Valle, que se venera en su santuario inmediato a la villa de Manzanilla. Imprenta Odiel, Huelva, 1938, pp. 3-4. GONZÁLEZ GÓMEZ, Juan Miguel y Manuel CARRASCO TERRIZA: Escultura Mariana Onubense. Op. cit., pp. 417-418.

31. Agradecemos a D. Felipe López Rincón y a D. Francisco Reyes Villadiego las informaciones que nos han facilitado sobre esta imagen de la Soledad. 
juntas, los ojos arrasados en lágrimas. Unas veces, con la mirada baja, desolada y abatida; otras, en esperanzada súplica ${ }^{32}$.

Esta Virgen de la Soledad de Morón de la Frontera, desde el punto de vista formal, ahonda en los postulados estéticos del academicismo sevillano de las postrimerías del Setecientos. La morbidez del óvalo de su rostro, el clasicismo de sus perfiles, el ritmo descendente de las cejas trazadas como a tiralíneas, la mirada baja y serena de sus llorosos ojos, la boca entreabierta, anhelante, deja ver la dentadura superior y la lengua, la palidez de las carnaciones, etc., subrayan el dolor letífico del semblante. En definitiva, todo responde al ideal de belleza femenina del momento (Lám. 3).

La armoniosa conjunción de la cabeza, inclinada suavemente hacia la derecha, con el esbelto cuello tubular acentúa la delicadeza emocional en la figura. Y, al unísono, sus manos entrelazadas, tan propias del modelo iconográfico y de la época, le confieren mayor intimismo al simulacro. En este sentido, baste recordar que María Santísima de las Aguas, cotitular de la Hermandad sevillana del Museo, en origen también tenía las manos unidas en atribulada súplica.

Esta Dolorosa sevillana, modelada en 1772 por Cristóbal Ramos, compañero de Blas Molner en la Real Escuela de las Tres Nobles Artes de Sevilla, ha sido objeto de varias restauraciones y transformaciones. Entre ellas, en 1922, Infantes Reina modificó su posición primigenia, arrodillada, adaptándole un nuevo candelero para colocarla en actitud erguida; y además, sustituyó sus manos entrelazadas, trabajadas en barro, por otras, talladas en madera, abiertas al gusto sevillano ${ }^{33}$.

La Virgen de la Soledad, que analizamos en el presente estudio, también ha sido restaurada en 1991, afortunadamente con mayor respeto al modelo original. La intervención corrió a cargo del joven imaginero Francisco Reyes Villadiego. Con tal motivo, sustituyó el antiguo candelero, apolillado, por otro nuevo de ocho listones. Dicha estructura lignaria, trabajada en pino de flandes, se dispone desde el busto hasta la base de la imagen. Tuvo el acierto de mantener los brazos primitivos, articulados sólo en los hombros, donde adaptó nuevas galletas para facilitar el movimiento de los mismos. Las manos unidas, de jugoso modelado, talladas independientemente de los brazos, se encajan en ellos con sendas espigas. De esta forma se posibilita la indumentaria de la Virgen. Y eliminó las

32. TRENS, Manuel: María. Iconografía de la Virgen en el Arte Español, Madrid, 1947, pp. 233-242. GONZÁLEZ GÓMEZ, Juan Miguel y CARRASCO TERRIZA, Manuel Jesús: Escultura Mariana Onubense. Op. cit., p. 271.

32. GONZÁLEZ GÓMEZ, Juan Miguel: "Imágenes de las cofradías sevillanas desde el Academicismo al Expresionismo realista”. Op. cit., p. 124. GONZÁLEZ GÓMEZ, Juan Miguel y RODA PEÑA, José: Imaginería procesional de la Semana Santa de Sevilla. Op. cit., p. 142. 
pletinas ajustadas a los hombros para sostener la ráfaga con que completaba su atuendo esta Dolorosa, como signo y símbolo de su glorificación.

Tan refulgente pieza de orfebrería ha caído en desuso en Sevilla y provincia. Se ha restringido, prácticamente, a las imágenes marianas de gloria. No obstante, se sigue considerando la gran señal apocalíptica: "una mujer vestida de sol, la luna bajo sus pies y sobre su cabeza una corona de doce estrellas" (Apoc. 12, 1). Por tanto, la ráfaga de rayos, alusiva al vestido de sol, cuando la ostenta una Dolorosa alude, de igual modo, a la Concepción Inmaculada de María. De esta forma, la Virgen, interpretada como Reina del Dolor, recuerda que Ella fue exenta del pecado original en previsión de los méritos conseguidos por Cristo en su pasión y muerte ${ }^{34}$.

Tras este breve comentario iconográfico, retomamos el hilo expositivo sobre el proceso restaurador de la Soledad de Morón de la Frontera. Francisco Reyes, de inmediato, resanó las grietas existentes en la zona posterior de su tonsa cabeza. Este tipo de cabeza, popularmente llamada de "bombilla", está concebida para lucir tocas, ampulosos mantos y esplendentes coronas. Asimismo, restañó las grietas de la mascarilla donde aparecieron superpuestas dos capas de policromía. La superficial era de pintura sintética, suavizada con maquillaje. Razón por la que fue eliminada, ya que ocultaba la encarnadura inferior, nacarada, que debía ser la original. Dicha capa pictórica se desprendió a base de bisturí, tanto en la mascarilla como en las manos. En seguida, se fijó la película pictórica, se estucaron las lagunas existentes para ser reintegradas posteriormente con las mismas tonalidades que la encarnadura propia. Para finalizar, en los ojos de cristal se pusieron nuevas pestañas postizas, para matizar adecuadamente la mirada; y en sus tersas mejillas se repusieron cinco lágrimas cristalinas.

Y nada más. Sin embargo, para facilitar la visión de conjunto de esta escultura, tan sólo nos resta describir someramente su actual indumentaria. Obviamente, el ropaje en las imágenes de vestir tiene una especial significación, ya que puede potenciar o disminuir los aciertos de la talla. La Virgen de la Soledad, objeto del presente estudio, viste saya de terciopelo rojo bordado en recorte, tocado de encaje color de té, manto de terciopelo azul marino liso y toca de sobremanto de malla dorada. Estas prendas fueron confeccionadas en el taller de bordados de la Vera-Cruz de Salteras (Sevilla). La corona, que ajusta sus sienes, se compone de canasto, imperiales y resplandor. Es una pieza reciente, inspirada en la de Nuestra Señora de las Tristezas, cotitular de la Hermandad de la VeraCruz de Sevilla. En la cruceta interior posee una inscripción que da a conocer la autoría y fecha de ejecución de la obra. Textualmente reza así: "ORFEBRERÍA MACARENA, 1991" (Lám. 4).

34. GONZÁLEZ GÓMEZ, Juan Miguel: Presentación del Catálogo Mater Dolorosa, Sevilla, 1988, pp. 9-10. 


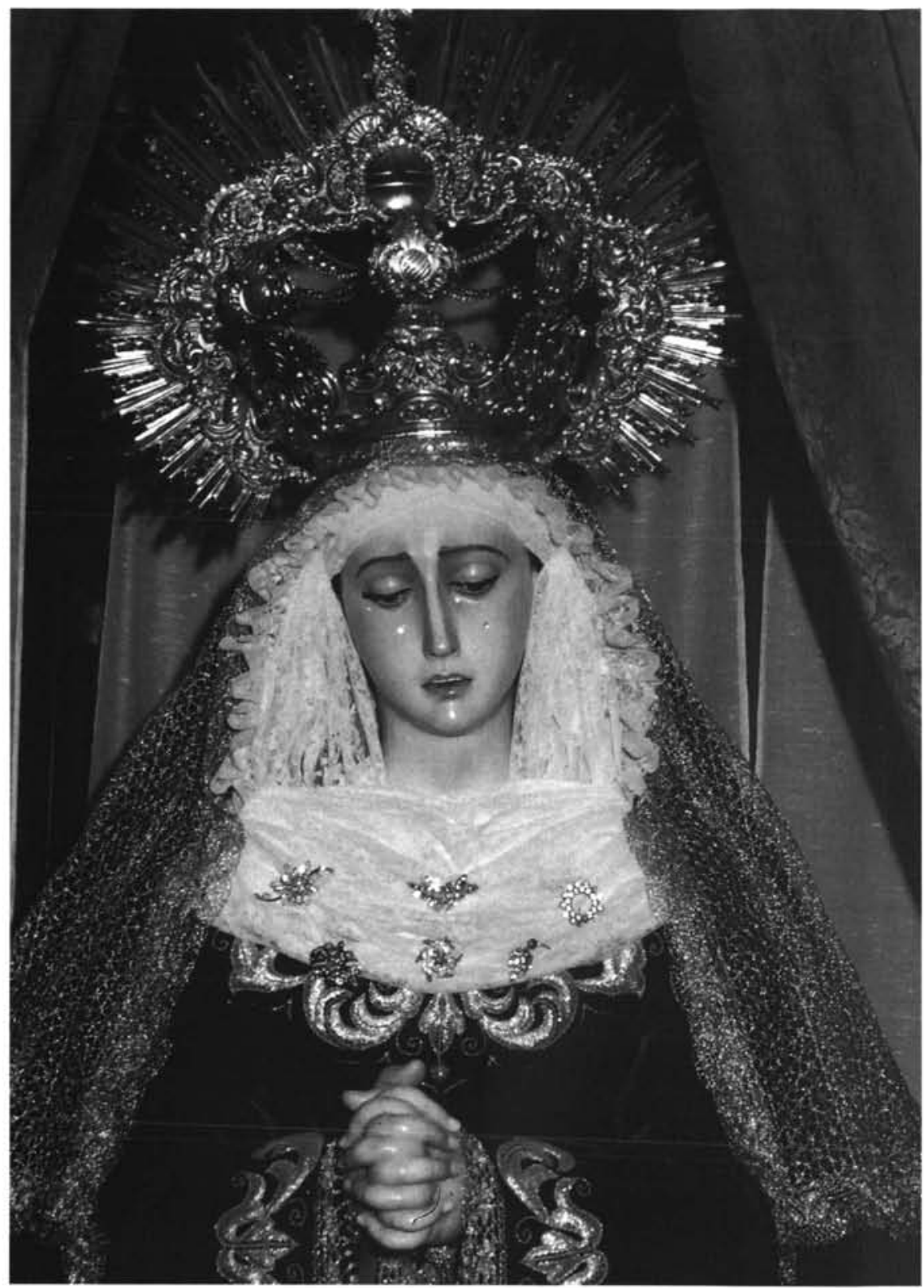

Lám. 1.

Virgen de la Soledad. Morón de la Frontera 


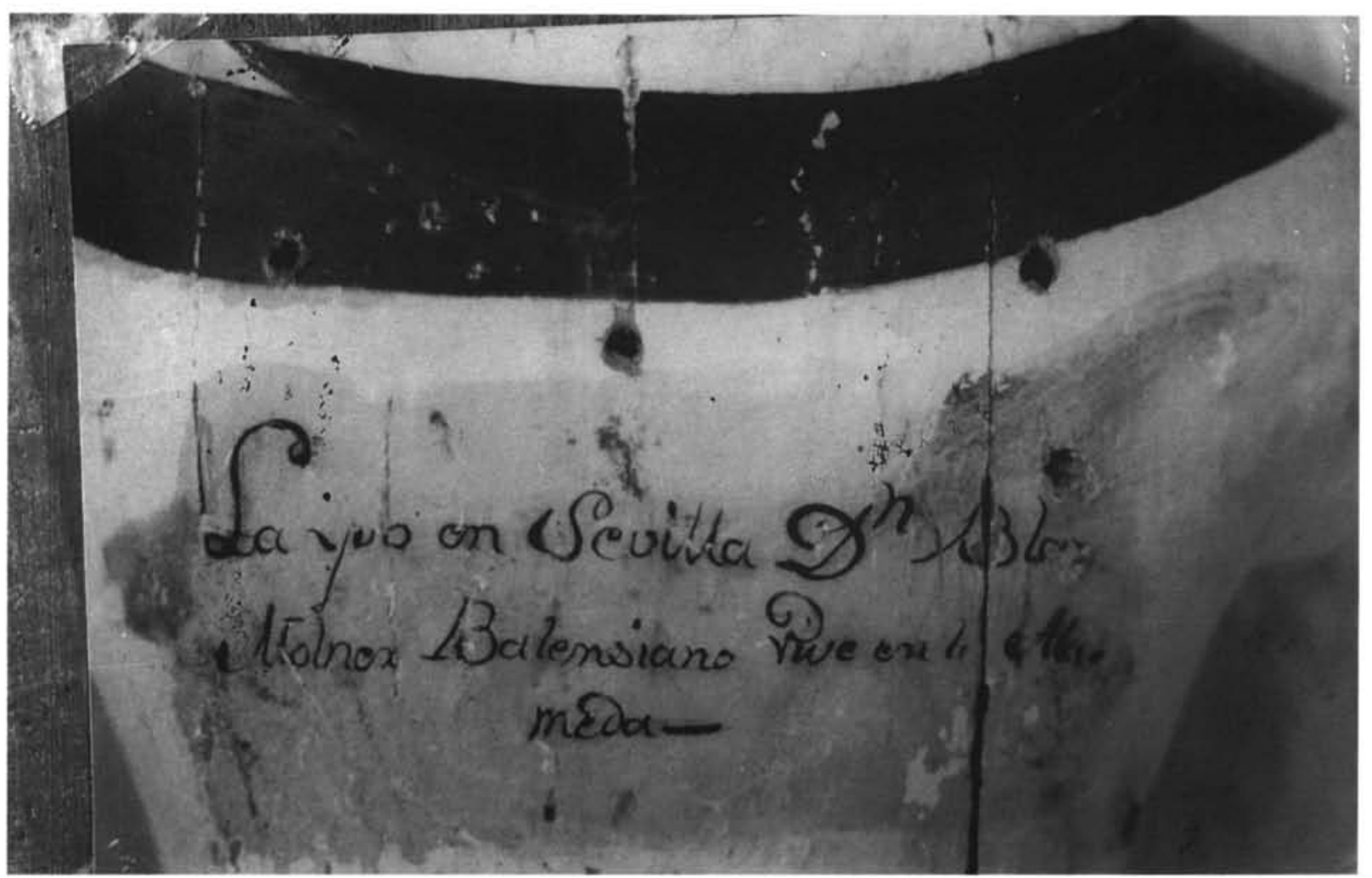




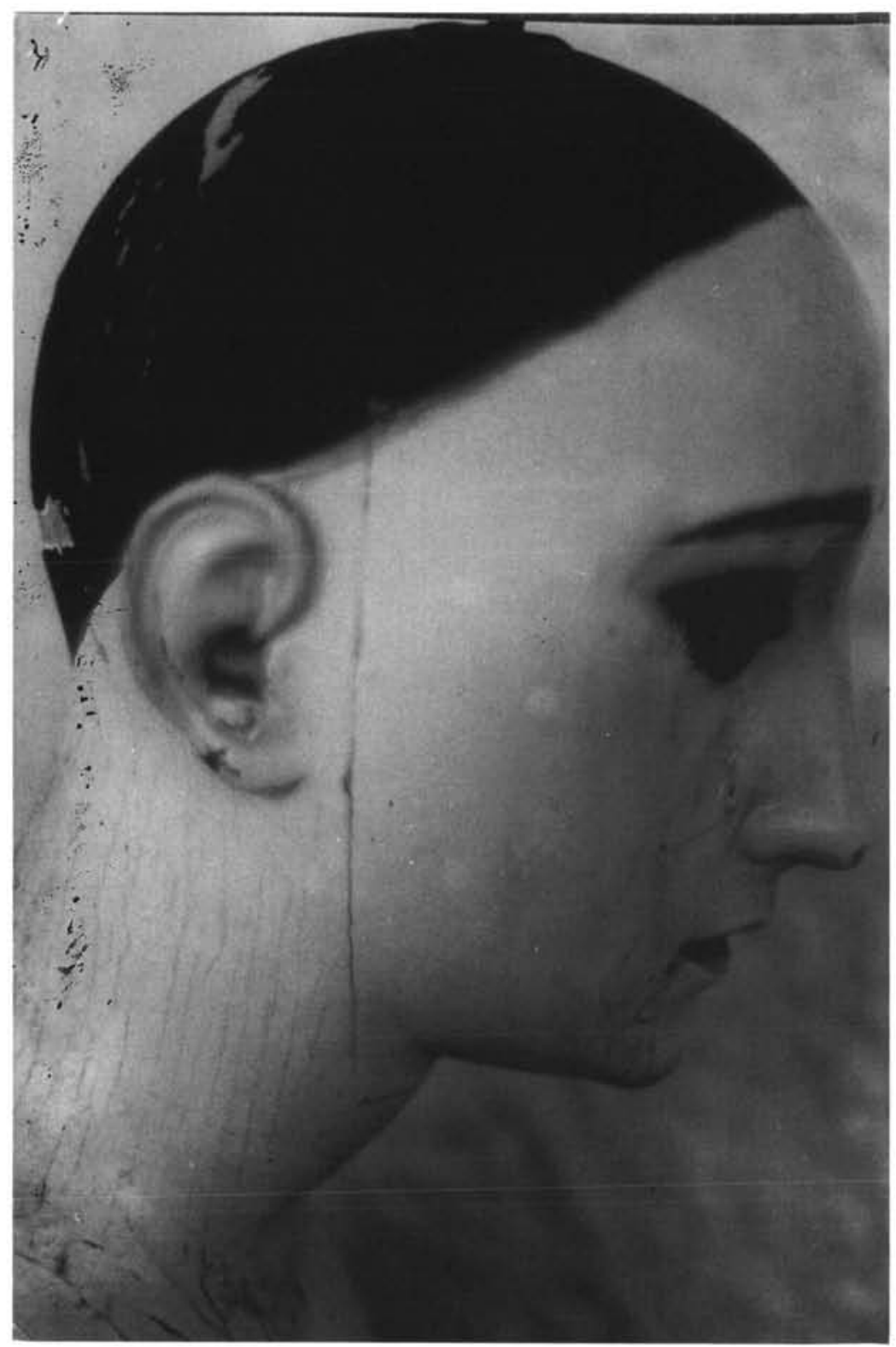

Lám. 3.

Perfil de la Virgen de la Soledad de Morón de la Frontera. 


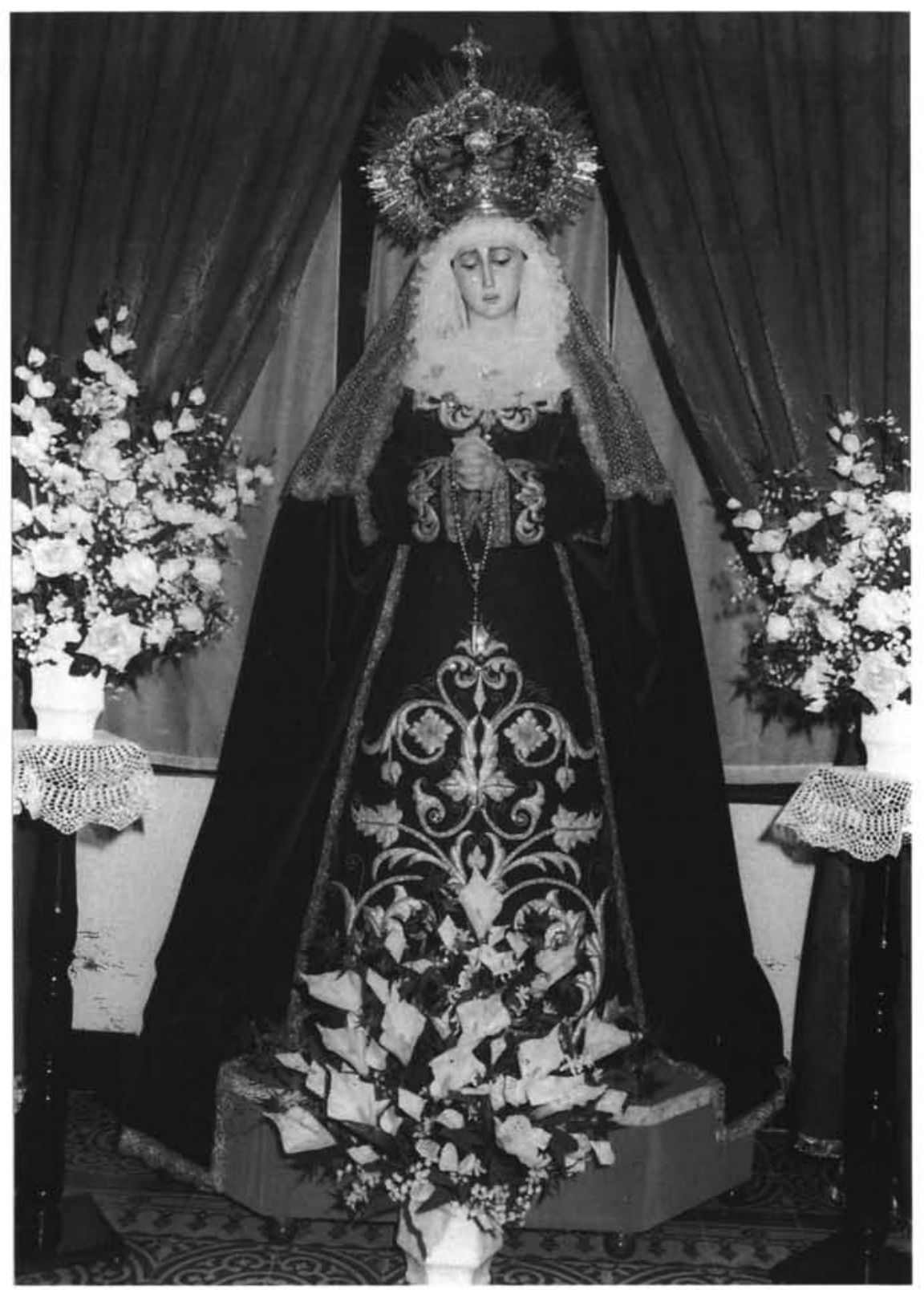

Lám. 4.

Virgen de la Soledad de Morón de la Frontera. 